\title{
Re-evaluation of Manganese Solubility as Affected by Soil Sample Preparation in the Laboratory
}

\author{
Emilene Andrade, Mário Miyazawa, Marcos Antonio Pavan* and Edson Lima de Oliveira \\ Instituto Agronômico do Paraná - IAPAR; C. P. 481; 86001-970; Londrina -PR - Brasil
}

\begin{abstract}
Laboratory experiments were conducted to re-evaluate the effects of drying and the time between drying and Mn analysis on soil Mn solubility using maize seedlings as test plant. Samples of five soil types were collected in the field, transferred to laboratory and submitted for the following treatments: dried in the shade at $25^{\circ} \mathrm{C}$ and dried at $65^{\circ} \mathrm{C}$ followed by Mn determination immediately and after 30 and 60 days. Ninety days later soil samples were rewetted at field capacity and maize seedlings were grown for 7 days. Evaluations included plant Mn content and soil Mn extracted with $\mathrm{NH}_{4} \mathrm{OAc} 1 \mathrm{~mol} \mathrm{~L} \mathrm{~L}^{-1} \mathrm{pH}$ 7. The lowest soil and plant Mn contents were found in soil samples dried in the shade at $25^{\circ} \mathrm{C}$. Drying soil sample at $65^{\circ} \mathrm{C}$ and increasing the time between drying and Mn analysis increased Mn solubility and Mn uptake by maize. Oxisols showed higher soil and plant Mn contents than other soil types. The results indicated the extreme difficulty in interpreting soil Mn results due to the great effect of soil processes in the laboratory on Mn solubility. Routine soil analysis is not recommended to evaluate plant available $\mathrm{Mn}$.
\end{abstract}

Key words: Micronutrient, transition metal, soil analysis

\section{INTRODUCTION}

Oxi-reduction reaction and $\mathrm{pH}$ are the main factors that control soil Mn solubility (Lindsay, 1979). Thus, the physical chemistry bases to predict $\mathrm{Mn}$ toxicity is much more complex than that for $\mathrm{Al}$ toxicity, for exemplo, due to the effect of $\mathrm{pH} / \mathrm{pe}$ relationship on Mn solubility. Many examples have been presented in the literature to demonstrate that soil sample preparation in the laboratory, such as drying temperature, time between drying and analysis, storage time, etc., changes Mn solubility (Fujimori and Shermam, 1945; Miyazawa et al., 1991 and 1996). Pavan and Miyazawa (1984) and Andrade et al. (2002) reported that the handling of soil sample in the field, soil moisture, temperature, sun light and organic matter content also exert great control on
Mn solubity. They also reported that the efficiency of $\mathrm{Mn}$ extractant solution to estimate $\mathrm{Mn}$ bioavaliability was extremely poor due to the effects in the field and during soil sample preparation in the laboratory.

There are conflicting reports on the efficacy of $\mathrm{Mn}$ extractant solutions for soil fertility purpose. In same cases no correlaction between soil $\mathrm{Mn}$ and plant Mn was observed (Reisenawer, 1988; Smith and Peterson, 1995; Miyazawa et al., 1991 and 1996) whereas in others the relationship appeared to be quite good (Muraoka et al., 1983; Borkert et al.; 1984). There appears to be no unifying thread through these observations on which predicting plant available soil $\mathrm{Mn}$ level can be based. The problem with many of these observations was that the condictions under which these works were carrried out (soil handling, soil

\footnotetext{
Author for correspondence
} 
prepartion, etc.) were often not described in sufficient details for meaningful interpretation to be made. Because of the importance of $\mathrm{Mn}$ on plant nutrition, there is a need to re-evaluate the efficacy of soil Mn analysis in relation to plant responses.

\section{MATERIAL AND METHODS}

The experiment was conducted under greenhouse condictions Seven soil types were collected in the field from cultivated sites potentially used for crop production in the state of Paraná.

Table 1 presents the sites and the main soil characteristics determined according to procedures described by Pavan et al. (1992).

Table 1 - Sites and chemical characteristics of soils.

\begin{tabular}{|c|c|c|c|c|c|c|c|}
\hline Site & Soil Type & $\begin{array}{c}\mathbf{p H ~ C a C l} \\
0.01 \mathrm{M}\end{array}$ & Al & $\mathbf{C a}$ & Mg & $\mathbf{K}$ & $\mathrm{C}$ \\
\hline & & & & \multicolumn{3}{|c|}{$\mathrm{cmol}_{\mathrm{c}} \mathrm{dm}^{-3}$} & $\mathrm{~g} \mathrm{~kg}^{-1}$ \\
\hline Cascavel & $\operatorname{LVdf}^{1)}$ & 4.6 & 0.3 & 6.0 & 2.6 & 0.6 & 48 \\
\hline Londrina & $\mathrm{LVdf}^{2)}$ & 4.2 & 0.9 & 2.4 & 0.9 & 0.2 & 17 \\
\hline Ortigueira & LVd & 5.7 & 0.0 & 7.1 & 1.9 & 0.5 & 27 \\
\hline Palotina & NVef & 4.9 & 0.1 & 4.1 & 1.5 & 0.6 & 12 \\
\hline Curitiba & $\mathrm{CXbd}^{1)}$ & 5.2 & 0.0 & 6.7 & 3.5 & 0.3 & 33 \\
\hline Ponta Grossa & $\mathrm{CXbd}^{2)}$ & 4.5 & 0.7 & 4.0 & 2.4 & 0.6 & 49 \\
\hline Guarapuava & CXdf & 4.3 & 0.6 & 2.2 & 1.3 & 0.2 & 38 \\
\hline
\end{tabular}

After sampling, soils were submitted for the following treatments: dried in the shade at $25^{\circ} \mathrm{C}$ (TO); and at $65^{\circ} \mathrm{C}$ with $\mathrm{Mn}$ extracted immediately (T1) after 30 days (T2) and after 60 days (T3). An additional treatment was included using the soil sample dried at $65^{\circ} \mathrm{C}$, rewetted at 60 days to $0.1 \mathrm{MPa}$ moisture content and $\mathrm{Mn}$ extracted immediately (T4) and after 30 days (T5). After each treatment, soil samples were transferred to plastic pots $(3 \mathrm{~kg})$ and four pre-germinated maize seedlings were grown for 7 days. Each soil was considered an individual experiment and the treatments were arranged in a completely randomized block with three replicates. Aerial and root parts were collected separatedely, washed, dried at $65^{\circ} \mathrm{C}$, milled to pass through $1 \mathrm{~mm}$ sieve and digested in a concentrated $\mathrm{HNO}_{3}$ and $\mathrm{HClO}_{4}$ mixture. Soil $\mathrm{Mn}$ was extracted with $\mathrm{NH}_{4} \mathrm{OA}_{\mathrm{c}}\left(1 \mathrm{~mol} \mathrm{~L}^{-1} \mathrm{pH}\right.$ 7.0) solution (1:10 soil: solution ratio), with 60 minutes shaking time, centrifuged at $2500 \mathrm{rpm}$ during 10 minutes and Mn was determined by Inductively Coupled Plasma (ICP). Soil and plant data were analyzed using proc anova procedures (SAS Institute, 1989) and the means were compared by Tukey test $(\mathrm{P}=0.05)$

\section{RESULTS AND DISCUSSION}

Soil Mn concentrations were significantly influenced by soil sample preparation treatments in the laboratory and varied from less than 1 to $150 \mathrm{mg} \mathrm{kg}^{-1}$, depending on soil type (Table 2).

The Oxisols ( LVdf and LVd) and the alfisol (NVef) presented greater Mn content than other soil types. These differences could be attributed to the soil parental material from which the soils were developed. Similar results were reported by Catani and Gallo (1951) who made a survey of Mn content in several soils from the state of São Paulo.

In general, drying soil samples in the shade presented the lowest Mn concentration and it did not statistically differ, except for $\mathrm{LVdf}^{2)}$, from which Mn concentration was determined 30 days after soil samples were rewetted. Drying soil samples at $65^{\circ}$ with $\mathrm{Mn}$ determination immediately increased $\mathrm{Mn}$ solubility as compared with shade (see T1, Table 2). This result could be extremely important because the Brazilian soil laboratories, generally,dry soil samples at $65^{\circ} \mathrm{C}$ for routine analysis. The process of drying soil samples increased $\mathrm{Mn}$ solubility which made much difficulties in interpreting $\mathrm{Mn}$ analytical results for soil fertility purpose. 
Table 2 - Soil sample preparation effect on soil Mn content.

\begin{tabular}{|c|c|c|c|c|c|c|c|}
\hline Treatments & $\mathbf{L V d f}^{1)}$ & LVdf $^{2)}$ & LVd & NVef & CXbd $^{1)}$ & CXbd $^{2)}$ & CXdf \\
\hline T0 & $5,2 \mathrm{c}$ & $22,1 \mathrm{e}$ & $0,4 d$ & $\begin{array}{r}\mathrm{mg} \mathrm{kg}{ }^{-1} \\
3,9 \mathrm{c}\end{array}$ & $0,4 b$ & $1,0 \mathrm{c}$ & $1,1 \mathrm{c}$ \\
\hline $\mathrm{T} 1$ & $42,6 b$ & $51,0 \mathrm{~d}$ & $58,2 \mathrm{c}$ & $39,2 b$ & $1,2 \mathrm{~b}$ & $5,4 \mathrm{~b}$ & $3,0 \mathrm{~b}$ \\
\hline $\mathrm{T} 2$ & $46,4 b$ & $66,0 \mathrm{c}$ & $69,6 \mathrm{cb}$ & $49,6 b$ & $1,0 \mathrm{~b}$ & $4,6 b$ & $3,1 b$ \\
\hline $\mathrm{T} 3$ & $76,8 \mathrm{a}$ & $97,6 a$ & $82,5 b$ & $56,2 b$ & $1,6 b$ & $6,0 \mathrm{~b}$ & $8,5 \mathrm{a}$ \\
\hline $\mathrm{T} 4$ & $89,2 \mathrm{a}$ & $81,2 b$ & $150,2 \mathrm{a}$ & $115,8 \mathrm{a}$ & $5,0 \mathrm{a}$ & $13,0 \mathrm{a}$ & $7,6 a$ \\
\hline T5 & $4,4 \mathrm{c}$ & $3,1 \mathrm{f}$ & $14,0 \mathrm{~d}$ & $3,4 \mathrm{c}$ & $1,1 \mathrm{~b}$ & $1,7 \mathrm{c}$ & $1,3 \mathrm{c}$ \\
\hline F test & $70,64 * *$ & $194,63 * *$ & $156,51 * *$ & $49,35 * *$ & $44,54 * *$ & $61,52 * *$ & $131,55^{* *}$ \\
\hline
\end{tabular}

Table 3 - Soil sample preparation effect on Mn content in the aerial part of maize seedlings

\begin{tabular}{|c|c|c|c|c|c|c|c|}
\hline Treatments & LVdf $^{1)}$ & $\mathbf{L V d f ^ { 2 }}$ & LVd & NVef & CXbd $^{1)}$ & $\mathrm{CXbd}^{2)}$ & CXdf \\
\hline T0 & $75 c$ & $712 \mathrm{c}$ & $92 c$ & $\begin{array}{r}\mathrm{mg} \mathrm{kg}^{-1} \\
133 \mathrm{~d}\end{array}$ & $27 \mathrm{c}$ & $56 c$ & $106 c$ \\
\hline $\mathrm{T} 1$ & $237 b$ & $1550 \mathrm{bc}$ & $322 \mathrm{abc}$ & $708 c$ & $69 a$ & $109 b$ & $230 \mathrm{ab}$ \\
\hline $\mathrm{T} 2$ & $443 a$ & $2720 \mathrm{a}$ & $584 a$ & $1593 a$ & $76 a$ & $166 a$ & $294 a$ \\
\hline $\mathrm{T} 3$ & $297 b$ & $1887 \mathrm{ab}$ & $411 \mathrm{ab}$ & $1178 b$ & $41 b c$ & $100 b$ & $139 \mathrm{c}$ \\
\hline $\mathrm{T} 4$ & $321 b$ & $1949 \mathrm{ab}$ & $292 \mathrm{abc}$ & $732 c$ & $49 b$ & $103 b$ & $215 b$ \\
\hline T5 & $107 \mathrm{c}$ & $676 c$ & $139 b c$ & $288 d$ & $48 b$ & $73 b c$ & $90 \mathrm{c}$ \\
\hline $\mathrm{F}$ test & $64,15 * *$ & $16,97 * *$ & $7,86^{* *}$ & $58,64 * *$ & $25,63 * *$ & $26,30 * *$ & $33,17 * *$ \\
\hline
\end{tabular}

Table 4 - Effect of soil sample preparation on Mn content in the root part of maize seedlings

\begin{tabular}{|c|c|c|c|c|c|c|c|}
\hline Treatments & LVdf ${ }^{1)}$ & LVdf ${ }^{2)}$ & LVd & NVef & CXbd $^{1)}$ & CXbd $^{2)}$ & CXdf \\
\hline T0 & $192 b$ & $530 \mathrm{a}$ & $540 \mathrm{a}$ & $451 \mathrm{c}$ & $17 \mathrm{~b}$ & $45 c$ & $93 c$ \\
\hline $\mathrm{T} 1$ & $155 b$ & $667 \mathrm{a}$ & $412 \mathrm{a}$ & $409 \mathrm{c}$ & $40 \mathrm{~b}$ & $112 b c$ & $138 b$ \\
\hline $\mathrm{T} 2$ & $363 a$ & $1184 \mathrm{a}$ & $970 \mathrm{a}$ & $1037 \mathrm{a}$ & $81 \mathrm{a}$ & $259 a$ & $184 \mathrm{a}$ \\
\hline $\mathrm{T} 3$ & $273 \mathrm{ab}$ & $926 a$ & $761 \mathrm{a}$ & $817 b$ & $33 b$ & $123 b$ & $75 c$ \\
\hline F test & $13,44 * *$ & $3,61 \mathrm{~ns}$ & $2,00 \mathrm{~ns}$ & $157,54 * *$ & $13,61 * *$ & $35,58 * *$ & $87,59 * *$ \\
\hline
\end{tabular}

Increasing the time between drying soil sample and $\mathrm{Mn}$ analysis also increased $\mathrm{Mn}$ solubility, in four of seven soils studied (see T2 and T3, Table2). This result was in accordance with Pavan and Miyazawa (1984) and Miyazawa et al. (1991 and 1996), north American soils (Fujimori and Sherman, 1945; Reisenauer, 1988) and African soils (Gillier et al., 1992). This showed that the soil sample preparation in the laboratory has great effect on Mn solubility. Thus, the practical efficacy of routine soil Mn determination would be uncertain.

Tables 3 and 4 show the effects of soil sample treatments on Mn concentrations in the aerial and root parts of the maize seedlings, respectively. In a general way, the Mn concentration in the aerial plant part was higher than in the root part. Mn content in the aerial part of maize seedlings reflected the variation in the extractable $\mathrm{Mn}$ and showed the lowest values for soil dried under the shade and soil re-wetted and kept 30 days before sampling, except for $\mathrm{CXbd}^{1)}$. On the other hand, drying soil samples at $65^{\circ} \mathrm{C}$ and the time between drying and $\mathrm{Mn}$ analysis increased Mn solubility (Table 2) and as expected, increased Mn uptake by maize seedlings ( Table 3 and 4). Plants growing in Oxisols (LVdf and LVd) and alfisol (NVef) presented higher Mn concentration than those growing in other soil types. Thus, it could be expected that the Mn toxicity l was more likely to occur in these soils.

Although there were good correlation coefficients between soil $\mathrm{Mn}-\mathrm{NH}_{4} \mathrm{AO}_{\mathrm{c}} \mathrm{pH} 7.0$ with plant $\mathrm{Mn}$ in both aereal part $\left(\mathrm{r}=0.66^{*}\right)$ and root part $(\mathrm{r}=$ $\left.0.74^{*}\right)$, it only happened because Mn ions were released by soil preparation in the laboratory and were available and readily absorbed by the maize roots in a short growing period of time ( 7 days). However, it could be important to note that under field condition during growing season, that type of Mn was not available and the correlation was very poor as shown by Borkert et al. (2001). 
These findings emphasized the chemical complexity of $\mathrm{Mn}$ reactions in soil and the fact that a sound basis for estimating Mn bioavailability using routine soil analysis should be used with restriction. The fact that Brazilian laboratories dry soil samples at $65^{\circ} \mathrm{C}$ is not guarantee that it would be effective for $\mathrm{Mn}$ diagnostic. The limitation of soil Mn analysis, therefore, could be due to the routine of soil preparation in the laboratory than anything else.

\section{RESUMO}

Avaliou-se em condições de laboratório os efeitos da secagem da amostra de solo e do tempo entre a secagem e a determinação analítica na solubilidade do Mn, utilizando-se milho como planta indicadora. Coletaram-se amostras de cinco solos agrícolas, transferiram-se para o laboratório onde foram submetidas aos seguintes tratamentos: secas a sombra a $25^{\circ} \mathrm{C}$, secas a $65^{\circ} \mathrm{C}$ determinando-se o Mn imediatamente, aos 30 e 60 dias. Após 90 dias reumedeceu-se os solos e cultivou-se plantas de milho durante 7 dias. Avaliações incluem Mnplanta e Mn-solo extraído com a solução de $\mathrm{NH}_{4} \mathrm{AO}_{\mathrm{c}} 1 \mathrm{~mol} \mathrm{~L}^{-1} \mathrm{pH} 7.0$. Amostras de solo secas à sombra apresentaram os menores teores de Mn no solo e nos tecidos das plantas. A secagem do solo a $65^{\circ} \mathrm{C}$ e $\mathrm{o}$ tempo entre a secagem e a determinação aumentaram a solubilidade de $\mathrm{Mn}$ no solo e a absorção de Mn pelas plantas. Os oxisolos e o alfisolo apresentaram os maiores teores de Mn. Os resultados indicaram a extrema dificuldade na interpretação analítica de $\mathrm{Mn}$ no solo para fins de fertilidade, devido aos efeitos do preparo da amostra no laboratório na solubilidade do Mn. Analise rotineira de solo deve ser usada com ressalvas para avaliação da disponibilidade de Mn para as plantas.

\section{REFERENCES}

Andrade, E.; Miyazawa, M.; Pavan, M. A. and Oliveira, E. L. (2002), Effect of organic matter on manganese solubility. Braz. Arch. Biol. Tech., 45, 17-20.

Borkert, C. M.; Lantmann, A. F.; Palhano, J. B. and Sfredo, G. J. (1984), Determinaçao química do manganês absorvivel pela soja. In: Seminário Nacional de Pesquisa de Soja, 3, 1984. Campinas. Anais... Campinas : EMBRAPA/CNPS. (EMBRAPA/CNPS. Documentos, 7). pp. 879-887.
Borkert, C. M.; Pavan, M. A. and Bataglia, O. C. (2001), Disponibilidade e avaliação de elementos catiônicos: ferro e manganês. In: Ferreira, M. E.; Cruz, M. C. P.; van Raij, B. and Abreu, C. A. (Eds.). Micronutrientes e elementos tóxicos na agricultura. Jaboticabal : CNPq/FAPESP/POTAFOS. pp. 151-185.

Catani, R. A. and Gallo, J. R. (1951), A extração do manganês e suas formas de ocorrência em alguns solos do estado de São Paulo. Bragantia, 21, 255-266.

Fujimori, C. K. and Sherman, G. D. (1945), The effect of drying, heating, and wetting on the levels of exchangeable manganese in Hawaiian soils. Soil Sci. Soc. Am. Proc., 10,107-112.

Gillier, H. E.; Amiger, F.; Bradric, S. I.; Magirata, S.P.; Musail, C.; Fdjo, O.T. and Smithson, J. B. (1992), Toxic concentration of iron and manganese in leaves of Phaseolus vulgaris, growing on freely drained soils of pH 6.5 in northern Tanzania. Comm. Soil Sci. Pl. Anal., 23, 787-792.

Lindsay, W. L. (1979), Chemical equilibria in soils. New York : John Wiley and Sons. 449 pp.

Miyazawa, M.; Pavan, M. A.; Bloch, M. F. M.; Martin Neto, L. and Araujo, A. R. (1991), Efeito da temperatura de secagem do solo e extratores na solubilidade do manganês. R. Bras. Ci. Solo, 15, 225-227.

Miyazawa, M.; Pavan, M. A.; P. L.O. A.; Oliveira, E. L. de and Yamashita, M. (1996), Manganese dynamic in acid soils and uptake by maize seedlings. Comm. Soil Sci. Pl. Anal., 27, 2349-2359.

Muraoka, T.; Neptume, A.M. L. and Nascimento Filho, V. F. (1983), Avaliação da disponibilidade de zinco e manganês do solo para o feijoeiro II.Manganês. $R$. Bras. Ci. Solo, 7, 177-182.

Pavan, M. A. and Miyazawa, M. (1984), Disponibilidade de manganês no solo: dificuldades e problemas na interpretação da análise para fins de fertilidade. R. Bras. Ci. Solo, 8, 285-289.

Pavan, M. A.; Bloch, M. F.; Zempulski, H.C.; Myiazawa, M. and Zocoler, D. C. (1992), Manual de análise química de solo e controle de qualidade. Londrina : IAPAR. 38 pp. (Circular, 76).

Reisenauer, H. M. (1988), Determination of plantavailable soil manganese. In: Graham, R. D.; Hannam, R. J. and Uren, N. C. (Eds.). Manganese in soils and plants. Dordrecht : Kluwer Academic Publisher. pp. 87-98.

SAS Institute Inc., SAS/STAT, User's Guide. Version 6. 4. ed. Cary, 1989, v.2. 846 pp.

Smith, K. A. and Peterson, J. E. (1995), Manganese and cobalt. In: Heavy metals in soil, ed. B. J. Alloway. Blackwell Academic and Professional, London, pp. 224-244. 